\title{
Heat of combustion, degree of reduction and carbon content: 3 interrelated methods of estimating the construction cost of plant tissues
}

\author{
C Gary ${ }^{1 *}$, JS Frossard ${ }^{2}$, D Chenevard ${ }^{2}$ \\ 1 Carnegie Institution of Washington, Department of Plant Biology, 290, Panama Street, Stanford, CA 94305, USA; \\ 2 Unité associée bioclimatologie-PIAF (INRA - université Blaise-Pascal), centre de recherches de Clermont-Ferrand-Theix, \\ domaine de Crouelle, F63039 Clermont-Ferrand cedex 02, France
}

(Received 6 September 1994; accepted 5 March 1995)

\begin{abstract}
Summary - During the last decade, degree of reduction (calculated from elemental composition), heat of combustion and carbon content have been proposed as 3 ways of estimating the construction cost of plant tissues. There is a fairly good agreement among these 3 methods, as they are all based on the link between the energy content of biomass and its reduction level. This relationship is not absolute and the regression coefficient between heat of combustion and degree of reduction may vary according to the chemical composition of biomass. The relation between degree of reduction and carbon content is implicitly based on the consequences in terms of molecular weight of the replacement of 1 oxygen atom by 2 hydrogen atoms in the process of reduction of photoassimilates (carbohydrates) into the various biomass compounds. Different trends can be observed on woody and non-woody tissues, which get richer in energy by increasing their content in lignin and lipids, respectively. Finally, the biosynthetic efficiency is also affected by the chemical composition of biomass. Therefore, while these 3 methods provide efficient and fairly simple tools for the estimation of the construction cost of biomass, they should not be used without considering what the dominant compounds of the plant tissues under study are and without choosing proper parameters in consequence.
\end{abstract}

construction cost / growth yield / heat of combustion / elemental analysis / carbon content / energy content / Juglans regia $L=$ walnut

Résumé - Chaleur de combustion, degré de réduction et teneur en carbone : 3 méthodes voisines d'estimation du coût de croissance des tissus végétaux. Au cours des dernières années, 3 méthodes nouvelles d'estimation du coût de synthèse de la biomasse ont été proposées, à partir de son degré de réduction (calculé grâce à sa composition élémentaire), de sa chaleur de combustion ou bien de sa teneur en carbone. Ces 3 méthodes donnent des résultats comparables car elles reposent toutes sur une relation générale entre le contenu énergétique de la biomasse et son niveau de réduction. On n'observe pourtant pas de corrélation parfaite entre ces résultats car le coefficient de régression entre chaleur de combustion et degré de réduction varie avec la composition chimique des tissus végétaux analysés. La relation entre degré de réduction et teneur en carbone est implicitement basée sur les conséquences pondérales du remplacement d'un atome d'oxygène par 2 atomes d'hydrogène au cours de la réduction des assimilats en divers constituants de la biomasse. De fait, on observe des comportements différents pour les tissus

* Correspondence and reprints. Present address: INRA, unité de bioclimatologie, domaine Saint-Paul, site Agroparc, F84914 Avignon cedex 9 , France 
ligneux et non-ligneux, qui deviennent riches en énergie par accumulation respectivement de lipides et de lignine. Enfin, l'efficience biosynthétique est également sensible à la composition chimique de la biomasse. Par conséquent, si les 3 méthodes présentées dans cet article constituent un ensemble cohérent d'outils opérationnels et relativement simples d'estimation du coût de synthèse de la biomasse, elles ne doivent pas être utilisées sans connaître quels sont les composants dominants du matériel végétal étudié et sans en tirer des conséquences pour le choix des paramètres des relations proposées.

efficience de croissance / chaleur de combustion / analyse élémentaire / teneur en carbone / contenu énergétique /Juglans regia $L=$ noyer

\section{INTRODUCTION}

In the process of plant tissue construction, photoassimilates (carbohydrates such as glucose) provide carbon skeletons for the synthesis of a whole range of organic compounds. The reduction level, ie the number of electrons per mole of these compounds, varies (Roels, 1983). It is sometimes lower (in the case of organic acids) and more often higher (eg, in the case of amino acids or lipids) than that of carbohydrates. Therefore, some extra amount of this substrate generally has to be oxidized into $\mathrm{CO}_{2}$ to provide electrons for the reduction of carbon, sulfur, and nitrogen if necessary, during the biosynthesis of new tissues. In addition, a further supply of carbohydrate is necessary to produce chemical energy to ensure the transport of substrates to the sites of biosynthesis and the polymerization of monomers. This energy is provided by the total oxidation of substrate by molecular oxygen into $\mathrm{CO}_{2}$ and $\mathrm{H}_{2} \mathrm{O}$. The ratio of the weight of tissue produced to the total weight of substrate consumed is the growth yield, $Y_{G}$ (Thornley, 1970), or production value, PV (Penning de Vries et al, 1974; a list of parameters used in this field by various authors is included in table I). The construction cost, $C$ (Williams et al, 1987), is the inverse of the growth yield (excluding cost of translocation) and is expressed as the sum of 3 terms, namely, the amount of carbohydrate (glucose) used to provide carbon skeletons $\left(g_{c}\right)$, the reducing power $\left(g_{r}\right)$ and the chemical energy $\left(g_{o}\right)$ per amount of biomass formed (McDermitt and Loomis, 1981):

$$
C=g_{c}+g_{r}+g_{o}
$$

Chemical energy used for the maintenance of living tissues is not considered in the calculation of the cost of construction.

Different techniques have led to estimations of growth yield (see Lambers et al, 1983, for a detailed discussion). One is based on correlations between night respiration and either daily photosynthesis (McCree, 1970) or daily growth (Szaniawski and Kielkiewicz, 1982); the growth yield is directly calculated from the slope of such linear relationships.

A second approach involves an analysis of the biochemical pathways leading to the synthesis of all biomass compounds and the calculation of the weight of glucose required for the production of carbon skeletons, for the supply of reducing power and of chemical energy and for the translocations contributing to the formation of a unit weight of biomass (Penning de Vries et al, 1974). The total content in carbohydrates, nitrogenous compounds, lipids, organic acids and lignin of the organic fraction of biomass are sufficient for the computation of growth yield, if assumptions are made on the composition of these 5 classes of compounds.

A third approach involves a separate estimate of the sum $g_{B}=g_{c}+g_{r}$ named 'glucose equivalent' which appears in the expression of the construction cost (equation [1]). During the combustion of plant tissue, the energy available in the carbon skeletons and associated with their reduction is released; dividing this heat value $\left(\Delta H_{c}\right.$, in $\left.\mathrm{kJ} \mathrm{g}^{-1}\right)$ by the heat of combustion of glucose $\left(15.65 \mathrm{~kJ} \mathrm{~g}^{-1}\right)$ leads to an approximation of the glucose equivalent:

$$
g_{B}=\Delta H_{C} / 15.65
$$

In fact, the heat of combustion is related to the enthalpy of oxidation of all the main elements in $\mathrm{CO}_{2}, \mathrm{H}_{2} \mathrm{O}, \mathrm{N}_{2}$ (or $\mathrm{NO}_{3}{ }^{-}$) and $\mathrm{SO}_{2}$ (or $\mathrm{SO}_{4}{ }^{2-}$ ) in a calorimeter. While $\mathrm{CO}_{2}$ and $\mathrm{H}_{2} \mathrm{O}$ are the sources of carbon and hydrogen in plants, nitrogen and sulfur can be used in reduced $\left(\mathrm{NH}_{4}{ }^{+}, \mathrm{H}_{2} \mathrm{~S}\right)$ or oxidized $\left(\mathrm{NO}_{3}{ }^{-}, \mathrm{SO}_{4}{ }^{2-}\right)$ forms. Thus, the heat of combustion allows an estimation of $g_{B}$, provided a correction is made for the contribution of the nitrogen source (sulfur content is generally low enough to be ignored) in the degree of reduction of the plant tissue (Williams et al, 1987).

Moreover, the glucose equivalent and the heat of combustion can be predicted using the calcu- 
lation of the generalized degree of reduction, $\gamma$, provided the elemental composition of biomass is determined. This concept is commonly used in microbiology (Roels, 1983; Sandler and Orbey, 1991) and represents the number of available electrons per mole product:

$$
\gamma=4 c+h-2 x+k n
$$

where $c, h, x$ and $n$ indicate the number of atoms of carbon, hydrogen, oxygen and nitrogen, respectively, per mole product; they are multiplied by the valences of these atoms in their ground state $\left(\mathrm{CO}_{2}, \mathrm{H}_{2} \mathrm{O}\right)$. For nitrogen, $\mathrm{k}=0, \mathrm{k}=$ +5 or $\mathrm{k}=-3$ if $\mathrm{N}_{2}$ (after combustion), $\mathrm{NO}_{3}{ }^{-}$or $\mathrm{NH}_{4}{ }^{+}$(in the process of plant tissue construction) are taken as the reference level. For plant bio-

Table I. Parameters used in different methods of estimating the construction cost of biomass.

Parameter

Growth yield

Production value

Glucose equivalent

Glucose value

Growth efficiency

Glucose equivalent

Generalized degree of reduction

Inverse of production value

Inverse of glucose value

Construction cost

Glucose equivalent

Glucose equivalent

Biosynthetic efficiency
Symbol Definition

$Y_{G} \quad$ Biomass formed from $1 \mathrm{~g}$ substrate (glucose)

PV Product (or biomass) formed from $1 \mathrm{~g}$ glucose, including the supply of carbon skeletons, reductant, ATP and translocation, same as $Y_{G}$ at the whole plant level

GE Glucose required to provide carbon and reductant for 1 mole product

GV Product (or biomass) formed from $1 \mathrm{~g}$ glucose, including only the supply of carbon and reductant

$E_{G} \quad P V / G V$, fraction of substrate electrons retained in the product

$g_{C} \quad$ Glucose required to provide carbon for $1 \mathrm{~g}$ product

$g_{r} \quad$ Glucose required to provide reductant for $1 \mathrm{~g}$ product

$g_{B} \quad g_{B}=g_{C}+g_{r}=1 / G V$

$g_{0} \quad$ Glucose required to provide ATP for $1 \mathrm{~g}$ product

Number of electrons per mole product

Glucose required to supply carbon, reductant, ATP and translocation for $1 \mathrm{~g}$ biomass

GVI Glucose required to supply carbon and reductant for $1 \mathrm{~g}$ biomass, same as $g_{B}$

C Same as $P V I$, excluding cost of translocation

$G E^{\prime} \quad 1 / G V$; glucose required to provide carbon and reductant for $1 \mathrm{~g}$ product

$G E_{o}^{\prime} G E$ with the oxidation number of the nitrogen and sulfur combustion products

$E_{B} \quad G E^{\prime} / C$, same as $E_{G}$, excluding cost of translocation

\section{Unit Reference}

$\mathrm{g} \mathrm{g}^{-1}$

$\mathrm{g} \mathrm{g}^{-1}$

$\mathrm{mol} \mathrm{mol}-1$

$\mathrm{g} \mathrm{g}^{-1}$

$\mathrm{mol} \mathrm{mol}^{-1}$

$g g^{-1}$

$\mathrm{g} \mathrm{g}^{-1}$

$\mathrm{g} \mathrm{g}^{-1}$

$\mathrm{g} \mathrm{g}^{-1}$

$\mathrm{mol} \mathrm{mol}^{-1}$

$\mathrm{g} \mathrm{g}^{-1}$

$g^{-1}$

$\mathrm{g} \mathrm{g}^{-1}$

$\mathrm{g} \mathrm{g}^{-1}$

$g g^{-1}$

$\mathrm{mol} \mathrm{mol}^{-1}$

(1) Thornley, 1970; (2) Penning de Vries et al, 1974; (3) McDermitt and Loomis, 1981; (4) Roels, 1983; (5) Vertregt and Penning de Vries, 1987; (6) Williams et al, 1987. 
mass, $\gamma, c, h, x$ and $n$ are usually expressed in moles per gram organic biomass; with such units we will write these variables $\gamma^{\prime}, c^{\prime}, h^{\prime}, x^{\prime}$ and $n^{\prime}$, respectively. Considering that the oxidation of one mole of glucose provides 24 moles of electrons, $G E=\gamma / 24$ is the amount of glucose containing the same number of electrons as one mole product (McDermitt and Loomis, 1981), an expression of the glucose equivalent in moles glucose per mole product. Then:

$$
g_{B}=\gamma^{\prime}(180.15 / 24)
$$

where $180.15 \mathrm{~g} \mathrm{~mol}^{-1}$ is the molar mass of glucose. Combining equation [2] and [4] leads to the relationship:

$$
\Delta H_{C}=117.5 \gamma^{\prime}
$$

$\gamma^{\prime}$ calculated here with $n^{\prime}=0$.

Finally, there is a positive correlation between the glucose equivalent and the carbon content of the organic fraction of a plant tissue (Vertregt and Penning de Vries, 1987). The contribution of carbon to the total mass of a molecule should indeed increase with the replacement of $\mathrm{C}=\mathrm{O}$ bonds by $\mathrm{C}-\mathrm{H}$ bonds during the reduction of this molecule. A few experimental data were used to verify this relation and its predictive quality was discussed for low carbon contents (Lafitte and Loomis, 1988; Walton et al, 1990). The same kind of correlation, between heat of combustion and carbon content, is used in fuel engineering, but different correlations were found for charcoals and for biomass materials (Graboski and Bain, 1981).

There is no way to estimate directly $g_{0}$, but the ratio

$$
E_{B}=\left(g_{C}+g_{r}\right) /\left(g_{C}+g_{r}+g_{o}\right)=g_{B} / C
$$

named 'biosynthetic efficiency', presents a low variability among plant tissues: $0.89 \pm 0.05$ (mean $\pm \mathrm{sd}$ ) on rice seed, wood, maize seedlings and Diplacus leaves (Williams et al, 1987). McDermitt and Loomis (1981) defined $E_{G}=g_{B} \times P V$ as 'growth efficiency', a parameter that also varies little: $0.88 \pm 0.02$ on seeds or caryopses of 13 crop species (McDermitt and Loomis, 1981); and $0.84 \pm 0.01$ on shoots of grain sorghum at 3 developmental stages and 2 levels of nitrogen supply (Lafitte and Loomis, 1988). When adding an estimated transport cost (one mole ATP per mole glucose required) to their construction cost, Williams et al (1987) transformed $E_{B}$ into $E_{G}$ around 0.87 .
This paper examines the relationships between heat of combustion, degree of reduction and carbon content of biomass, with different data sets presenting a large range of energy contents. It aims at providing guidelines for a proper use of these recent methods of estimating the construction cost of plant tissues in ecology and crop physiology studies. Correlations between heat of combustion and degree of reduction, or glucose equivalent, were calculated from tables of organic compounds by various authors (McDermitt and Loomis, 1981; Roels, 1983; Williams et al, 1987; Sandler and Orbey, 1991); they are verified and discussed here in relation to measurements on plant tissues. The same data sets made it possible to discuss the relation between degree of reduction and carbon content. The composition of biomass affects this correlation and this explains discrepancies among various authors working on plant tissues having different major compounds (Vertregt and Penning de Vries, 1987; Lafitte and Loomis, 1988; Walton et al, 1990).

\section{MATERIALS AND METHODS}

Three previously published sets of data were used, combining measurements of heat of combustion and elemental composition on various plant tissues. A fourth is original and contains heat of combustion and carbon content measurements (table II) of different parts of walnut (Juglans regia $L$ ) seedlings during germination. Proximal analyses were also available for part of set 1 (Merino et al, 1984) and for set 3 (Walton and de Jong, 1990), while only lipid and carbohydrate content was measured in set 4 . All data were expressed per gram organic biomass, and the mineral fraction was estimated to be $67 \%$ of the ash content (Vertregt and Penning de Vries, 1987).

In the fourth set of data, heat of combustion was measured with an adiabatic calorimeter at constant volume. Combustion gases passed through a mixture of soda lime and sodium hydroxide; the weight change of this mixture during combustion represented the mass of $\mathrm{CO}_{2}$ that was converted into mass of carbon. After correction by the amount of $\mathrm{CO}_{2}$ remaining in the calorimeter at the end of the experiment, the carbon content of the sample was calculated. After combustion, the ashes were weighed to determine the ash content (Frossard et al, 1992). The lipid content of the kernel was evaluated by NMR, using crude walnut oil as the reference. Soluble carbohydrates were extracted in boiling ethanol $(80 \% \mathrm{v} / \mathrm{v})$ and assayed by the anthrone method (Halhoul and Kleinberg, 1972). Starch was assayed from the ethanol-extracted residue, as previously reported (Frossard and Friaud, 1989). Soluble carbohydrates and starch were both expressed in grams of glucose. 
Table II. Characteristics of the different data sets.

Data set

1 1

2

2

2

3

4

4
Author(s)

Williams, 1986
Williams et al, 1987
Jenkins, 1989
Jenkins, 1989
Jenkins, 1989
Walton et al, 1990
Original data
Original data

Species

Various

Chaparral shrubs

Field and energy crops

Forest and fruit trees

Food and fiber wastes

Kiwifruit

Walnut seedlings

Walnut seedlings
Plant tissue

Sample number

\section{RESULTS AND DISCUSSION}

\section{Heat of combustion and degree of reduction}

The explanation of the heat of combustion of a compound by its degree of reduction can be roughly verified on the organic fraction of plant biomass through a multiple regression of heat of combustion $\left(\Delta H_{C}\right.$, in $\left.\mathrm{kJ} \mathrm{g}^{-1}\right)$ versus carbon, hydrogen, oxygen and nitrogen contents $\left(c^{\prime}, h^{\prime}, \boldsymbol{x}^{\prime}\right.$ and $n^{\prime}$, respectively, in mol $\mathrm{g}^{-1}$ ). Backwards multiple regression enabled us to eliminate $n^{\prime}$ as a significant explicative variable, as expected from the final reduction state of nitrogen after combustion $\left(\mathrm{N}_{2}\right)$ :

$$
\Delta H_{c}=109.2\left(4 c^{\prime}+0.83 h^{\prime}-1.21 x^{\prime}\right)
$$

(data sets 1, 2 and 3 ; $d f=114, r^{2}=0.998$, SE of the estimate $=0.508$ )

When the multiplicative factor of $c^{\prime}$ is set to 4 (valence of carbon), the multiplicative factors of $h^{\prime}$ and $x^{\prime}$ are fairly far from the valences of these elements even if the signs are correct.

Plant tissues do not offer a range of combinations of carbon, hydrogen and oxygen contents large enough to find multiplicative factors closer to the valences of these elements, as Sandler and Orbey (1991) did from a table of 96 organic compounds. The multiplicative factor of the expression within brackets $\left(109.2 \mathrm{~kJ} \mathrm{~mol}^{-1}\right.$ electron) is not far from published values of the heat of combustion associated with the displacement of one mole of electrons (see below).

Using the practical definition of the generalized degree of reduction $\gamma^{\prime}=4 c^{\prime}+h^{\prime}-2 x^{\prime}$, the data points for the heat of combustion are fairly well correlated with $\gamma^{\prime}($ fig 1 ):

$\begin{array}{lr}\text { Various } & 29 \\ \text { Leaves } & 14 \\ \text { Straw, wood } & 18 \\ \text { Wood } & 23 \\ \text { Various } & 20 \\ \text { Berries } & 12 \\ \text { Kernel } & 5 \\ \text { All plant organs } & 8\end{array}$

$\Delta H_{C}=115.4 \gamma^{\prime}$

(data sets 1, 2 and $3 ; d f=117, r^{2}=0.857$, SE of the estimate $=0.909$ )

The origin was set to zero in equation [6] and [7] as expected from theoretical calculations (equation [5]). The slope of equation [7] is comparable to other estimations made from tables of organic compounds: $108-118 \mathrm{~kJ} \mathrm{~mol}^{-1}$ electron (recalculated from McDermitt and Loomis, 1981), $111 \mathrm{~kJ} \mathrm{~mol}^{-1}$ (Patel and Erickson, 1981), $115 \mathrm{~kJ}$ $\mathrm{mol}^{-1}$ (Roels, 1983), $108 \mathrm{~kJ} \mathrm{~mol}^{-1}$ (recalculated from Williams et al, 1987), $104 \mathrm{~kJ} \mathrm{~mol}^{-1}$ (Sandler and Orbey, 1991). These are not far from the theoretical value of $109 \mathrm{~kJ} \mathrm{~mol}^{-1}$ proposed by Kharasch and Sher (1925). Only microbiologists have previously checked this relation on biomass (bacteria or fungi); they found similar slopes of $112 \mathrm{~kJ} \mathrm{~mol}^{-1}$ (Minkevich and Eroshin, 1973; Ho and Payne, 1979).

However, these slight discrepancies among authors can be questioned. On figure 1, scattering is about $8 \%$ around mean values and it is bounded by 2 theoretical lines representing the same correlation recalculated from McDermitt and Loomis (1981) for carbohydrates (upper line) and for other compounds (lower line). Data set 3 is on the upper line; these samples were rich in carbohydrates (Walton and de Jong, 1990). Samples with the highest degree of reduction are rich in lipids (set 1; Merino et al, 1984) and lie close to the lower line. The difference between the 2 lines fits with the range of corrections (about $1.2 \mathrm{~kJ} \mathrm{~g}^{-1}$ ) some authors (Kharasch and Sher, 1925; Sandler and Orbey, 1991) suggested to account for the discrepancies they observed between measured and simulated (ie calculated from a fixed energy content per mole of electrons displaced) heats of combustion. There is a theoretical reason for such a variability. The degree of reduction, or glucose 


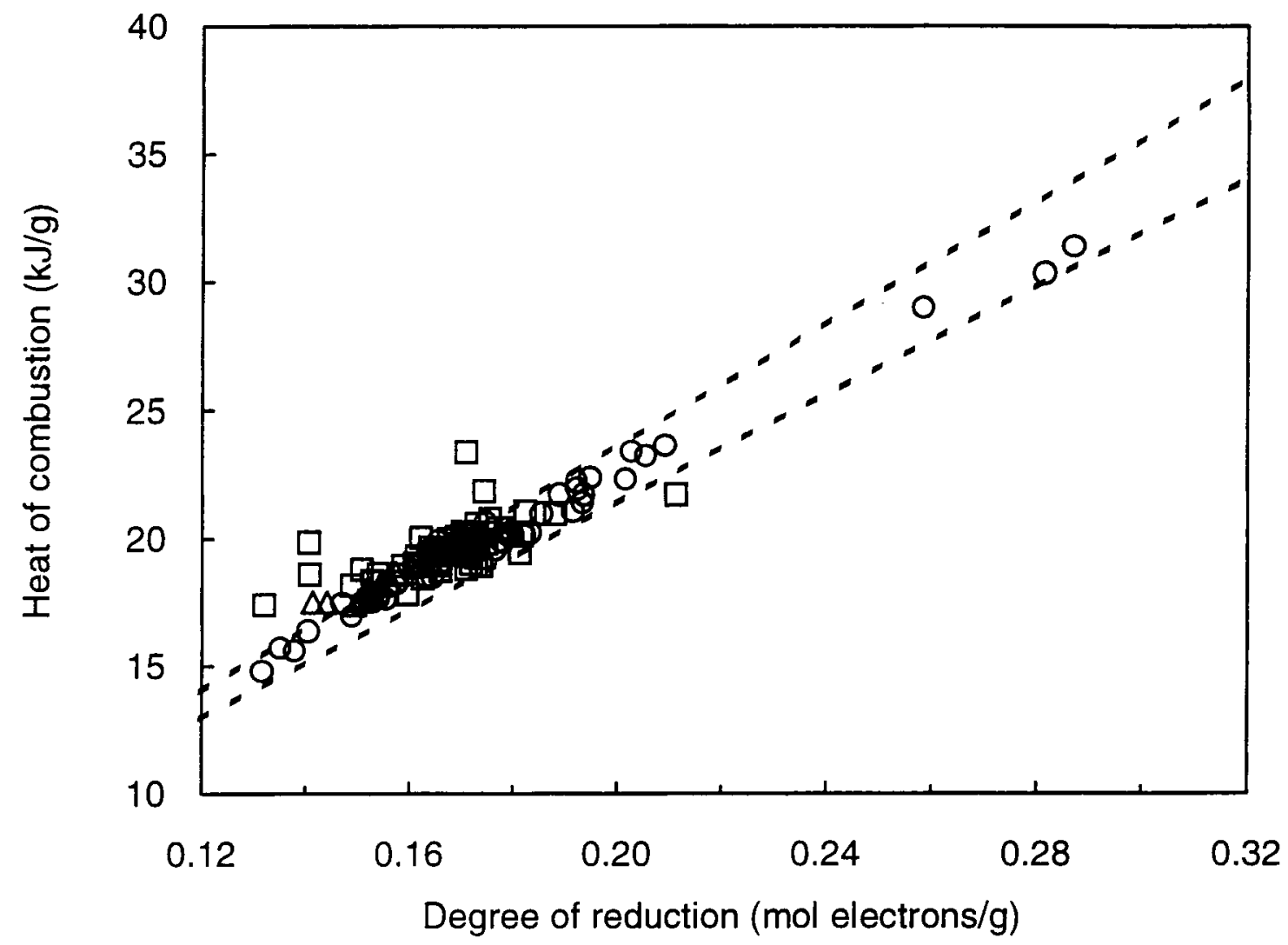

Fig 1. Heat of combustion and degree of reduction of various plant tissues (data sets 1: $0,2: \square$ and 3: $\Delta$ ). The 2 broken lines were recalculated (degree of reduction rather than glucose equivalent, expressed per gram rather than per mole product) from McDermitt and Loomis (1981) and represent the relationships for carbohydrates (upperline) and other organic compounds (lower line).

equivalent, provides information only on stoichiometry, whereas energy content can also be affected by the structure of the molecule(s). This is why the slope of equation [5], which is based on stoichiometry, fits with the higher slope calculated by McDermitt and Loomis (1981).

These results show (i) that there is a theoretical limit to the precision of prediction of heat of combustion from elemental analysis, and (ii) that the accuracy of measurement of these variables is generally good enough for them to fit into the theoretical range of errors; $72 \%$ of the experimental data lie between the 2 theoretical boundaries. Errors of measurement could explain the position of the remaining $28 \%$ samples, but they could not be identified. Microbiologists stressed the importance of a careful preparation of the dry biomass samples (Cordier et al, 1987; Gurakan et al, 1990).

\section{Heat of combustion and carbon content}

From all 4 sets of data, the correlation between heat of combustion and carbon content is verified (fig 2):

$$
\Delta H_{C}=720.4 c^{\prime}-9.34
$$

$\left(d f=129, r^{2}=0.915\right.$, SE of the estimate $\left.=1.059\right)$

Data set 2 seems to present a particular behaviour. For data sets 1,3 and 4 :

$$
\Delta H_{c}=754.3 c^{\prime}-10.47
$$

$\left(d f=68, r^{2}=0.967\right.$, SE of the estimate $\left.=0.716\right)$.

While for data set 2 :

$$
\Delta H_{c}=322.4 c^{\prime}+6.457
$$

$\left(d f=59, r^{2}=0.489\right.$, SE of the estimate $\left.=0.501\right)$.

The origin was not set to zero in equations [8] to [10], as $\Delta H_{C}$ can be equal to zero with positive $c^{\prime}$ (for $\mathrm{CO}_{2}$ ). Vertregt and Penning de Vries (1987) calculated a higher value for the slope of a similar relation, $870 \mathrm{~kJ} \mathrm{~mol}^{-1}$ (after multiplication of their glucose equivalents by the heat of combustion of glucose, namely $15.65 \mathrm{~kJ} \mathrm{~g}^{-1}$ ). This slope did not enable Lambers and Rychter (1989) and Walton et al (1990) to compute construction costs comparable with those acquired through other methods. Going back to Vertregt and Penning de Vries' data, Walton et al (1990) 


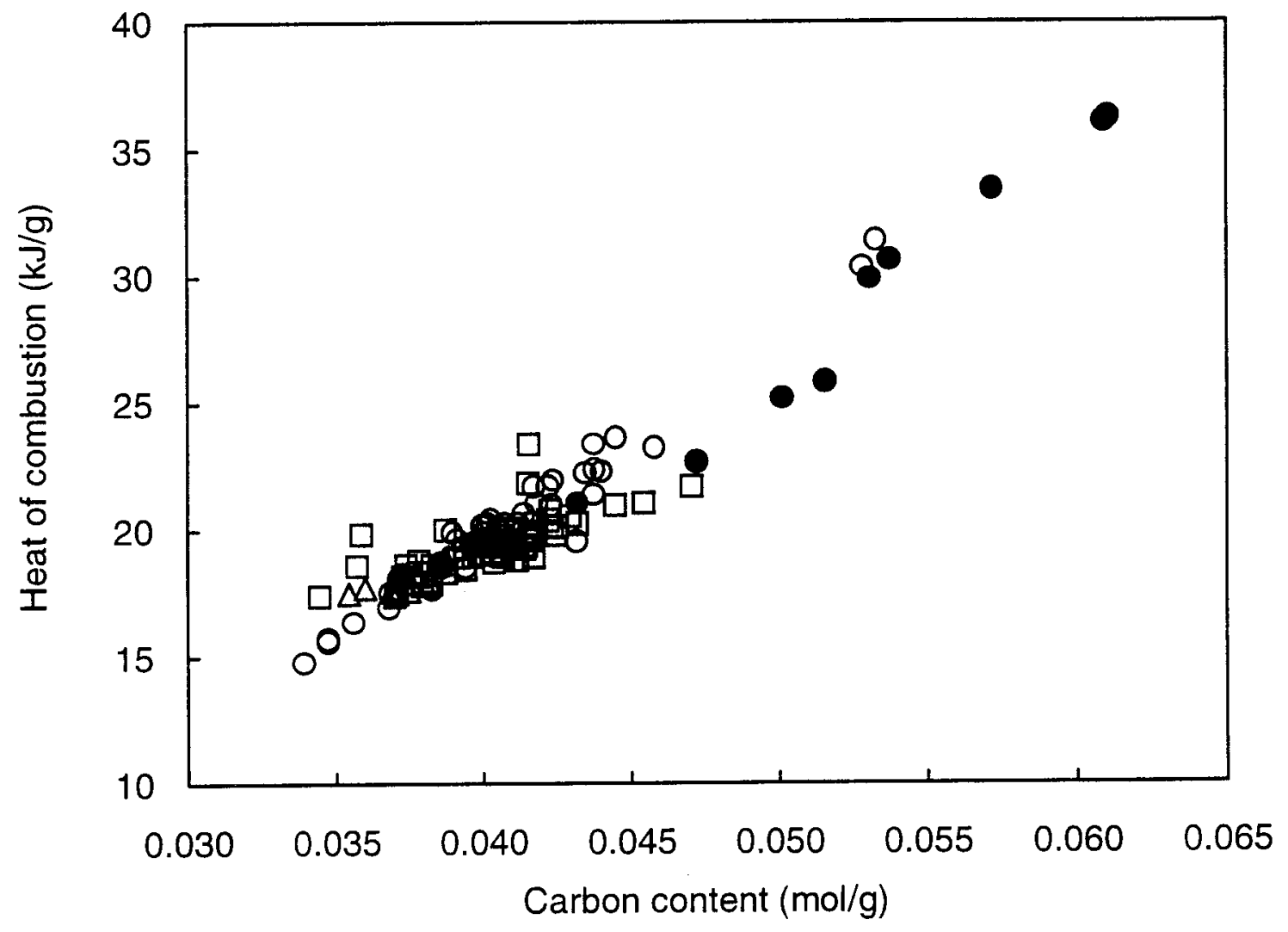

Fig 2. Heat of combustion and carbon content of various plant tissues (data sets 1: $O, 2: \square, 3$ : and 4:

found a lower slope for the range of low carbon contents they observed on their own samples: $648 \mathrm{~kJ} \mathrm{~mol}^{-1}$. In the field of fuel engineering, Tillman's equation (reported by Graboski and Bain, 1981) is used with a slope of $524 \mathrm{~kJ} \mathrm{~mol}^{-1}$. In microbiology, Ho and Payne (1979) proposed a model that, after analysis, is equivalent to the same linear relationship between heat of combustion and carbon content with a slope of $539 \mathrm{~kJ} \mathrm{~mol}^{-1}$.

It might be surprising that the heat of combustion is linearly correlated with both the carbon content and the degree of reduction. This can be explained considering that living matter is constituted of varying proportions of $\mathrm{C}=\mathrm{O}\left(\gamma=2 \mathrm{e}^{-} \mathrm{C}\right.$ $\mathrm{mol}^{-1}$ and $\left.c^{\prime}=1 / 28 \mathrm{~mol} \mathrm{C} \mathrm{g}^{-1}\right)$ and $\mathrm{C}-\mathrm{H}\left(\gamma=5 \mathrm{e}^{-}\right.$ $\mathrm{C}$-mol-1 and $c^{\prime}=1 / 13 \mathrm{~mol} \mathrm{C} \mathrm{g}^{-1}$ ) bonds, indicating a rough proportionally between $\gamma$ and $c^{\prime}$. This simple rule theoretically allows us to replace the degree of reduction, calculated from the analysis of 3 elements $(\mathrm{C}, \mathrm{H}$ and $\mathrm{O})$ by the content in only 1 of these elements, carbon. However, when a range of organic compounds with various degrees of reduction is considered, it can be observed that a higher degree of reduction can be reached either with a lower oxygen content or with a higher hydrogen content (fig 3). For example, although the heat of combustion is lower for organic acids than for carbohydrates, their carbon content is not very different; the same comparison can be made between lipids and lignin (fig 4). In contrast, there is a large difference in oxygen content between carbohydrates and organic acids on the one hand, and lipids and lignin on the other. This difference explains the larger carbon content of the latter.

In plant tissues, which are mixtures of these various compounds, differences in the way the degree of reduction is found are buffered, but not completely. The variability of heats of combustion of tissues having the highest carbon content, reaches $20 \%$ around a mean value (fig 2 ). Tissues belonging to data sets 1 and 4 present high levels of lipids (Merino et al, 1984, and table III), while those belonging to set 2 are woody tissues with high levels of lignin (Graboski and Bain, 1981; Jenkins, 1989). Consequently, the relationship between heat of combustion and carbon content is not independent of the chemical composition of biomass. When working on a specific plant material, we suggest calibrating equation [8]. 


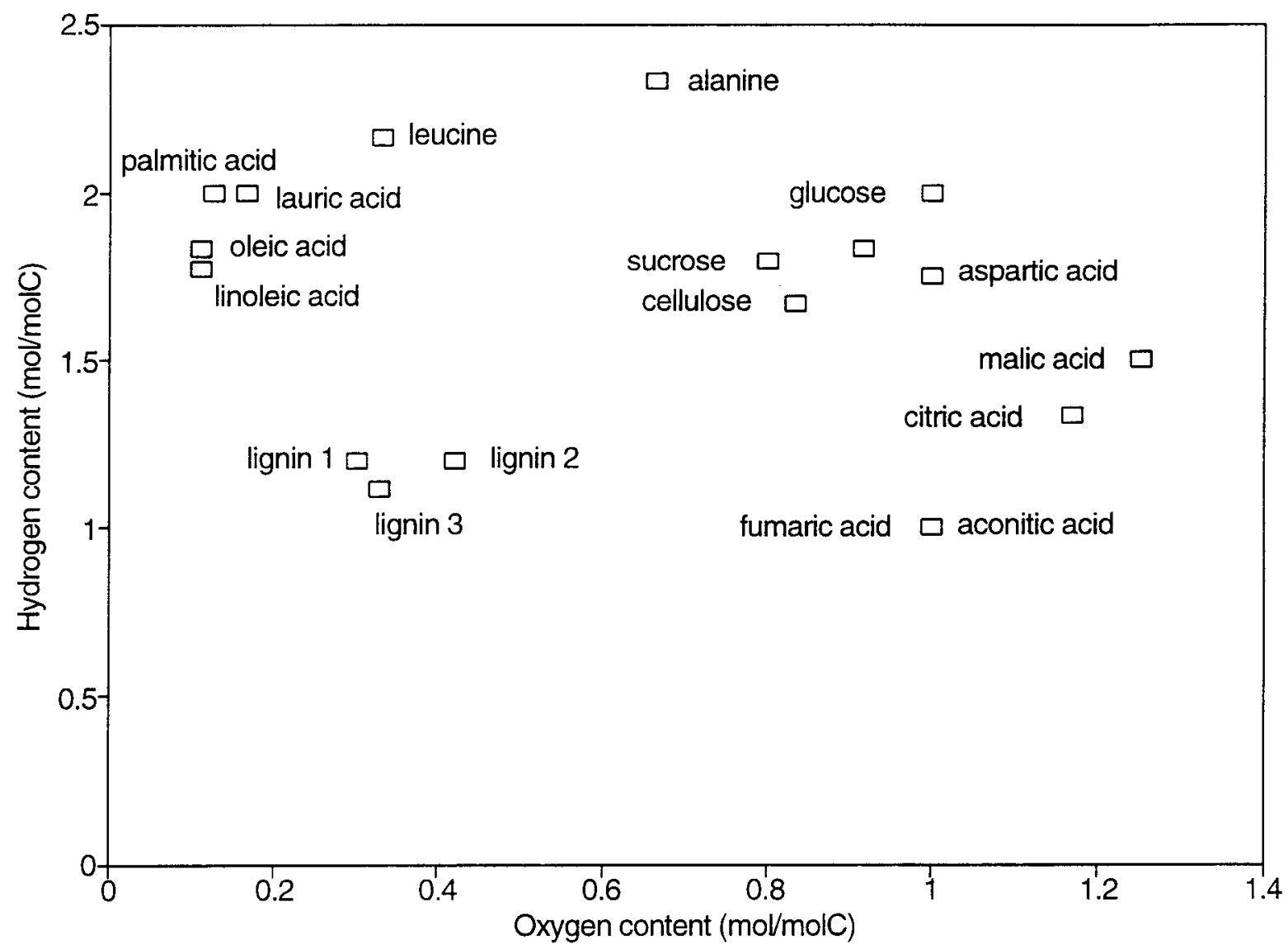

Fig 3. Hydrogen vs oxygen content of some common plant carbohydrates (glucose, sucrose and cellulose), amino acids (alanine, aspartic acid, glutamic acid and leucine), lipids (lauric acid, linoleic acid, oleic acid and palmitic acid), organic acids (aconitic acid, citric acid, fumaric acid and malic acid) and lignin. The elemental composition and heat of combustion of lignin varies with the source; 3 values were taken from Domalski et al (1987).

Table III. Heat of combustion and chemical composition of data set 4. Lipids were analysed only on kernels.

\begin{tabular}{|c|c|c|c|c|c|c|}
\hline $\begin{array}{l}\text { Harvest } \\
\text { number }\end{array}$ & Organ & $\begin{array}{l}\text { Heat of combustion } \\
\qquad\left(k J g^{-1} \text { d.wt }\right)\end{array}$ & $\begin{array}{l}\text { Carbon content } \\
\left(g g^{-1} d . w t\right)\end{array}$ & $\begin{array}{l}\text { Lipid content } \\
\left(g g^{-1} d . w t\right)\end{array}$ & $\begin{array}{l}\text { Carbohydrate content } \\
\qquad\left(g g^{-1} d . w t\right)\end{array}$ & $\begin{array}{l}\text { Ash content } \\
\left(g g^{-1} d . w t\right)\end{array}$ \\
\hline 1 & Kernel & 33.3 & 0.674 & 0.71 & 0.05 & 0.119 \\
\hline 2 & Kernel & 33.0 & 0.670 & 0.70 & 0.05 & 0.124 \\
\hline 3 & Kernel & 30.8 & 0.633 & 0.60 & 0.11 & 0.115 \\
\hline 4 & Kernel & 28.4 & 0.600 & 0.47 & 0.17 & 0.104 \\
\hline 5 & Kernel & 27.3 & 0.582 & 0.44 & 0.19 & 0.128 \\
\hline $2-5$ & Tap root & 17.3 & 0.423 & & 0.22 & 0.165 \\
\hline $2-3$ & Tap root & 17.0 & 0.420 & & 0.27 & 0.137 \\
\hline 5 & Tap root & 17.0 & 0.419 & & 0.26 & 0.090 \\
\hline $2-5$ & Tap root & 16.9 & 0.424 & & 0.19 & 0.376 \\
\hline $2-4$ & Stem & 17.7 & 0.436 & & 0.22 & 0.153 \\
\hline 5 & Stem & 17.7 & 0.437 & & 0.19 & 0.235 \\
\hline $3-4$ & Leaves & 19.0 & 0.455 & & 0.14 & 0.364 \\
\hline 5 & Leaves & 18.9 & 0.452 & & 0.14 & 0.403 \\
\hline
\end{tabular}




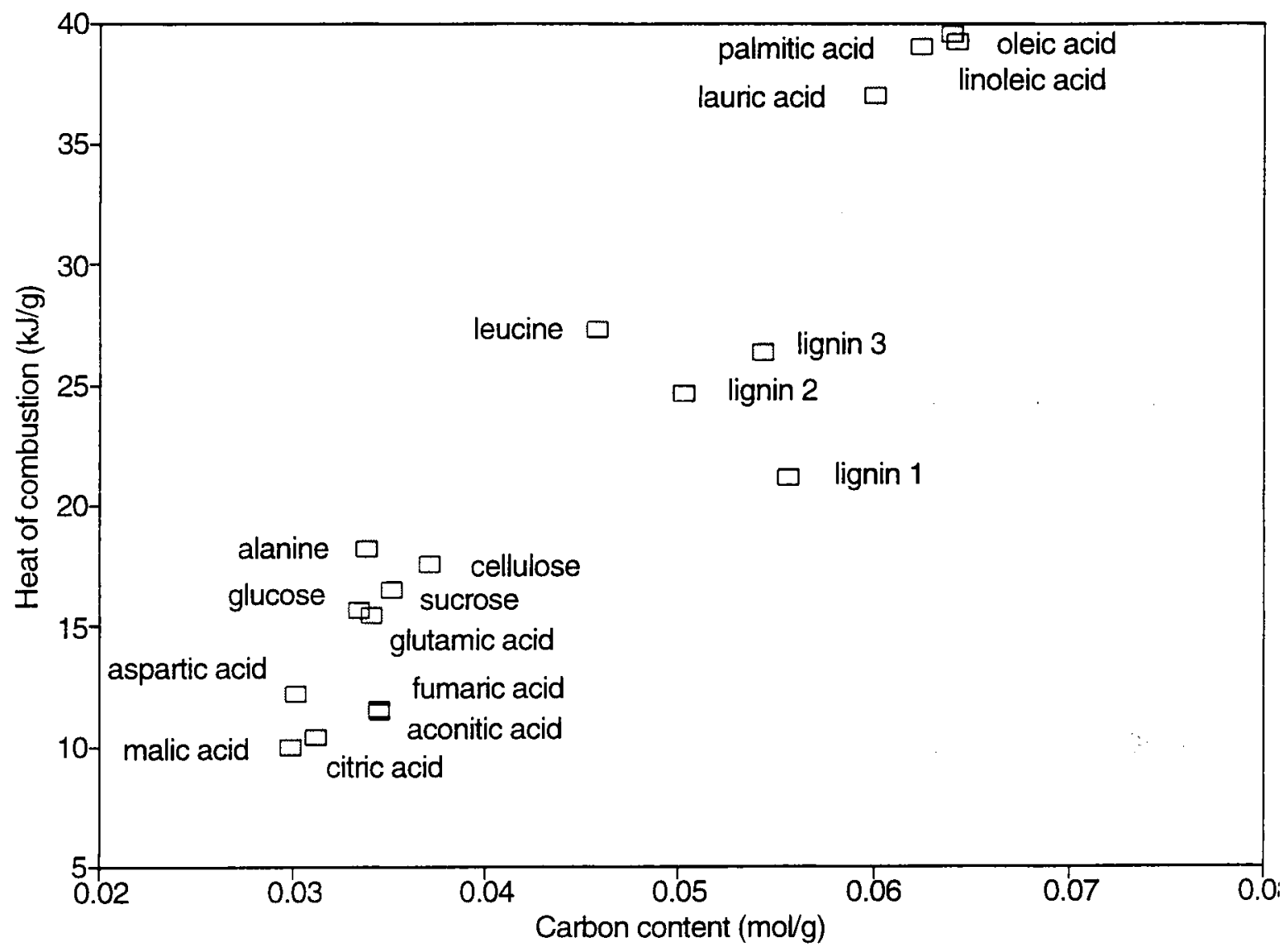

Fig 4. Heat of combustion (Kharasch, 1929) and carbon content of the same plant compounds as in figure 3.

\section{Estimation of the construction cost of plant tissues}

The heat of combustion, which can be measured or estimated from the degree of reduction (equation [5]), or the carbon content (equation [8]) can be used for the estimation of the construction cost. When the nitrogen source for growth is nitrate, the cost of reducing nitrate should be considered, as suggested by Williams et al (1987). This cost, $C_{N}$ (in grams glucose per gram biomass), is calculated as a function of the nitrogen content of biomass:

$$
C_{N}=k n^{\prime}(180.15 / 24)
$$

where $k$ is the degree of reduction of the nitrogen source, namely $\mathrm{k}=5$ for nitrate, $180.15 \mathrm{~g} \mathrm{~mol}^{-1}$ is the molar mass of glucose and 24 represents the number of moles of electrons provided by the oxidation of 1 mole glucose. The glucose equivalent, ie the total amount of glucose required to provide carbon skeletons, $g_{c}$, and reducing power, $g_{n}$ is then given by:

$$
g_{B}=g_{C}+g_{r}=0.0639 \Delta H_{C}+7.506 \mathrm{k} n^{\prime}
$$

which is equation [2] corrected by equation [11]. Finally, the construction cost is calculated by using the biosynthetic efficiency:

$$
C=g_{B} / E_{B}
$$

If $E_{B}$ is replaced by $E_{G}$ in equation [13], then $1 / Y_{G}$ is calculated instead of $C$ and transport cost is taken into account. Equations [5] or [8] and/or [12] together with equation [13] allow the calculation of the construction cost from any of the 3 methods (degree of reduction, carbon content and heat of combustion) compared in this paper. Note that all values are expressed here per gram organic biomass. There is no constant in equation [12], and so they can also be expressed per gram dry weight (organic biomass + ashes).

These 3 methods of estimating the construction cost of plant tissues were compared by Lafitte and Loomis (1988) and Walton et al (1990). The discrepancies they observed are of the same magnitude as the variability around the expressions [7] and [8] which we attributed to the 
chemical composition of the analysed tissues. Williams et al (1987) proposed a single mean linear relationship between heat of combustion and degree of reduction. For tissues rich in carbohydrates (kiwifruit berries in Walton et al, 1990), the use of this single relationship leads to an overestimation of the construction cost. For tissues richer in other compounds (Lafitte and Loomis, 1988), the same relationship may lead to an underestimation of the construction cost. Likewise, Walton et al (1990) suggested that the relationship between the inverse of glucose value (equivalent to $g_{B}$ ) and the carbon content published by Vertregt and Penning de Vries (1987) overestimated the construction cost of tissues rich in organic acids (Walton and de Jong, 1990). Note that biosynthetic efficiency itself is not independent of the composition of biomass; it is high for carbohydrates, organic acids (up to 0.95 ) and low for protein and lignin (down to 0.73 ; Williams et al, 1987). All these errors could be corrected by considering the chemical composition of the tissues, but it would greatly reduce the simplicity of the 3 methods examined in this paper.

Estimating the cost of producing new plant tissues from variables such as heat of combustion or elemental composition may seem crude in regard to the complexity of the biochemical processes involved. The major uncertainty lies in the estimation of the amount of substrate electrons that are not retained in the product. Biosynthetic efficiency $\left(E_{B}\right)$ was calculated from theoretical values of the construction cost, on the basis of the biochemical pathways used to synthesize the various tissue compounds (McDermitt and Loomis, 1981; Williams et al, 1987). The respiratory coefficient ( $\mathrm{P} / \mathrm{O}$ ratio) was set to 3 , but evidence for the existence of a wasteful respiratory pathway has been presented (Lambers and Rychter, 1989). However a change in the P/O ratio from 3 to 2 should not affect the construction cost more than by $5 \%$ (Penning de Vries et al, 1974). Transport cost is also estimated with a poor precision but again the growth yield is not very sensitive to it. Furthermore, the methods discussed in this paper have been designed and should be used for studies at the organ or whole plant level and over long time periods, when possible variations in the efficiency of energy production and use are likely to be buffered.

\section{CONCLUSION}

The heat of combustion, degree of reduction and carbon content are well correlated in plant tis- sues, and each of these variables may be used for the calculation of the construction cost of biomass. Heat of combustion is certainly the most direct way to estimate the construction cost, after division by the heat of combustion of glucose, correction for the possible cost of reduction of nitrogen and division by the biosynthetic efficiency. Going through a correlation between heat of combustion and glucose equivalent (Williams et al, 1987) and using the elemental composition for the calculation of the glucose equivalent (McDermitt and Loomis, 1981) may lead to errors theoretically limited to $8 \%$. Carbon content measurements are fairly simple and precise but they should be combined with a correction for the cost of reducing nitrogen. The chemical composition of biomass affects (i) the relationship between heat of combustion and degree of reduction; (ii) the relationship between carbon content and heat of combustion or construction cost; and (iii) the biosynthetic efficiency. In this paper, taking into account this chemical composition helped understand discrepancies between various authors. Before using any method, preliminary studies on the composition of the plant tissues under analysis or calibration of relationships like equation [8] would enable the choice of proper parameters.

\section{ACKNOWLEDGMENTS}

The first author is greatful to $C$ Field who gave him full facilities in his lab to contribute to this work and to RW Loomis and BM Jenkins who introduced him to the field of biomass engineering; INRA and the Conseil régional Provence-Alpes-Côte d'Azur supported his visit. G Dussap is acknowledged for his critical reading of the manuscript.

\section{REFERENCES}

Cordier JL, Butsch BM, Birou B, von Stockar U (1987) The relationship between elemental composition and heat of combustion of microbial biomass. Appl Microbiol Biotechnol 25, 305-312

Domalski ES, Lobe TL, Milne TA (1987) Thermodynamic Data for Biomass Materials and Waste Components. ASME, New York, USA

Frossard JS, Friaud JF (1989) Root temperature and short-term accumulation of carbohydrates in maize hybrids at early growth stage. agronomie 9, 941-947

Frossard JS, Chenevard D, Lacointe A, Gary C (1992) Energy balance in germinating walnuts (Juglans regia $\mathrm{L}$ ): evaluation of different approaches. In: Molecular, Biochemical and Physiological Aspects of Plant Respiration (H Lambers, LHW van der 
Plas, eds), SPB Academic Publishing, The Hague, The Netherlands, 529-534

Graboski M, Bain R (1981) Properties of biomass relevant to gasification. In: Biomass Gasification. Principles and Technology (TB Reed, ed) Noyes Data Corp, Park Ridge, USA, 41-71

Gurakan T, Marison IW, von Stockar U, Gustafsson L, Gnaiger E (1990) Proposals for a standardized sample handling procedure for the determination of elemental composition and enthalpy of combustion of biological material. Thermochim Acta 172, 251266

Halhoul MN, Kleinberg I (1972) Differential determination of glucose and fructose, and glucose- and fructose-yielding substances with anthrone. Anal Biochem 50, 337-343

Ho KP, Payne WJ (1979) Assimilation efficiency and energy contents of prototrophic bacteria. Biotechnol Bioeng 21, 787-802

Jenkins BM (1989) Physical properties of biomass. In: Biomass Handbook (O Kitani, CW Hall, eds) Gordon and Breach Science Publishers, New York, USA, 860-891

Kharasch MS (1929) Heats of combustion of organic compounds. J Res Nat/ Bur Stand 2, 359-430

Kharasch MS, Sher B (1925) The electronic conception of valence and heats of combustion of organic compounds. J Phys Chem 29, 625-658

Lafitte HR, Loomis RS (1988) Calculation of growth yield, growth respiration and heat content of grain sorghum from elemental and proximal analysis. Ann Bot 62, 353-361

Lambers H, Rychter AM (1989) The biochemical background of variation in respiration rate: respiratory pathways and chemical composition. In: Causes and Consequences of Variation in Growth Rate and Productivity of Higher Plants (H Lambers, ML Cambridge, $\mathrm{H}$ Konings, TL Pons, eds) SPB Academic Publishing, The Hague, The Netherlands, 199-225

Lambers H, Szaniawski RK, de Visser R (1983) Respiration for growth, maintenance and ion uptake. An evaluation of concepts, methods, values and their significance. Physiol Plant 58, 556-563

McCree KJ (1970) An equation for the rate of respiration of white clover plants grown under controlled conditions. In: Prediction and Measurement of Photosynthesis Productivity. Proceedings of the IBP/PP Technical Meeting, Trebon, Sept 1969 , PUDOC, Wageningen, The Netherlands, 221-229
McDermitt DK, Loomis RS (1981) Elemental composition of biomass and its relation to energy content, growth efficiency and growth yield. Ann Bot 48, 275290

Merino J, Field C, Mooney HA (1984) Construction and maintenance costs of mediterranean-climate evergreen and deciduous leaves. Acta Oecol Oecol Plant 5, 211-229

Minkevich IG, Eroshin VK (1973) Productivity and heat generation of fermentation under oxygen limitation. Folia Microbiol 18, 376-385

Patel SA, Erickson LE (1981) Estimation of heat of combustion of biomass from elemental analysis using available electron concepts. Biotechnol Bioeng 23, 2051-2067

Penning de Vries FWT, Brunsting AHM, van Laar $\mathrm{HH}$ (1974) Products, requirements and efficiency of biosynthesis: a quantitative approach. $J$ Theor Biol $45,339-377$

Roels AJ (1983) Energetics and Kinetics in Biotechnology. Elsevier Biomedical Press, Amsterdam, The Netherlands

Sandler SI, Orbey H (1991) On the thermodynamics of microbial growth processes. Biotechnol Bioeng 38 , 697-718

Szaniawski RK, Kielkiewicz M (1982) Maintenance and growth respiration in shoots and roots of sunflower plants at different root temperatures. Physiol Plant 54, 500-504

Thornley JHM (1970) Respiration, growth and maintenance in plants. Nature (Lond) 227, 304-305

Vertregt N, Penning de Vries FWT (1987) A rapid method for determining the efficiency of biosynthesis of plant biomass. $J$ Theor Biol 128, 109-119

Walton EF, de Jong TM (1990) Growth and compositional changes in kiwifruit berries from 3 californian locations. Ann Bot 66, 285-297

Walton EF, de Jong TM, Lommis RE (1990) Comparison of 4 methods calculating the seasonal pattern of plant growth efficiency of a kiwifruit berry. Ann Bot 66, 298-307

Williams K (1986) Estimating carbon and energy cost of plant tissues. PhD Dissertation, Stanford University, USA, $89 p$

Williams K, Percival F, Merino J, Mooney HA (1987) Estimation of tissue construction cost from heat of combustion and organic nitrogen content. Plant Cell Environ 10, 725-734 